\title{
The Difference Number of Bacterial Colonies between Smokers and Non-smokers Gingivitis Patients in Periodontics Department at USU Dental Hospital
}

\author{
Regina Carsa Bagin Apriani \\ Undergraduate Student \\ Faculty of Dentistry, Universitas Sumatera Utara \\ Medan, Indonesia
}

\author{
Pitu Wulandari \\ Department of Periodontics \\ Faculty of Dentistry, Universitas Sumatera Utara \\ Medan, Indonesia
}

\author{
Martina Amalia \\ Department of Periodontics \\ Faculty of Dentistry, Universitas Sumatera Utara \\ Medan, Indonesia
}

\begin{abstract}
Periodontal disease is a chronic inflammation disease which caused by bacteria in the periodontal tissues. The predisposing factors are smoking, stress and alcohol consumption. Smoking can deteriorate the dental health and increase the risk of gingivitis. Smoking may causes various diseases in oral cavities, such as stein formation on tooth surfaces. The tar, which settled on the teeth, will cause aesthetic problem and makes the teeth surfaces become rough. Thus it could easily cause plaque accumulation. Plaque-induced Gingivitis was related to the accumulation of bacterial plaque. The aim of this study was to analyze the difference number of bacterial colonies between smoker and non-smokers gingivitis patients in periodontics department at USU Dental Hospital. This research was a cross-sectional analytic study that uses the questionnaire and clinical examination such as gingival index, plaque control record and examination of the number of bacterial colonies. The examination was performed to 70 gingivitis patients, 35 who are smokers and 35 who are non-smokers. Based on non-parametric Mann-Whitney test result, there was significant difference $(p<0.05)$ between the number of bacterial colonies on smokers and non-smokers gingivitis patients $(p=0.001)$ and a significant difference $(p<0.005)$ between the accumulation of plaque in smokers and nonsmokers gingivitis patients $(p=0.008)$. As a conclusion, there were differences in the number of colonies of bacteria between smokers and non-smokers gingivitis patients and differences of plaque accumulation between smokers and non-smokers gingivitis patients.
\end{abstract}

Keywords-gingivitis, plaque, bacteria, periodontal, smokers

\section{INTRODUCTION}

Periodontal disease is a worldwide health problem and the most common disease, both children and adults $[1,2]$. Based on the survey conducted by National Institute of Dental Research (NIDR) in Indonesia, periodontal disease ranks second and is a major problem in the oral health community [2].

Periodontal disease is a chronic inflammatory disease caused by bacterial invasion in the periodontal tissues, which involves the gingiva, periodontal ligament, alveolar bone and cementum $[3,4]$. The main cause of periodontal disease is the colonization of microorganisms that firmly attached to the tooth surface. The bacterial colonies form the plaque that causes gingivitis [3].

Dental plaque is a soft layer that consists of microorganisms that proliferate and firmly attached to the tooth surface. One milligram to $1 \mathrm{~mm}^{3}$ dental plaque contains 200 million cells of microorganisms [5].

Periodontal disease can be affected by various factors including smoking, systemic diseases and genetic factors [6,7]. The large accumulation of microorganisms in the dental plaque is the trigger factor of periodontal disease [8].

The prevalence of smokers in Indonesia is growing every year [9]. Based on the results Riset Kesehatan Dasar (RISKESDAS) 2013, the prevalence of smokers population in Indonesia was $29.3 \%$ while in North Sumatra was $24.2 \%$ and the light smokers was only $4.2 \%[10]$

Smoking greatly affects the occurrence of periodontal disease. Periodontal tissue damage due to smoking begins with the accumulation of plaque [10]. Smoking causes changes in vascularity and salivary secretions that decrease salivary antibodies useful in neutralizing the bacteria in the oral cavity, causing impaired function of immune cells due to the heat generated smoke $[10,11]$. Changes in vascularity due to smoking cause enlargement of capillary blood vessels and infiltration of inflammatory agents that causing gingival enlargement. This condition was followed by the increasing number of lymphocytes and macrophages 
[11]. These changes resulted in an imbalance between the bacteria and the host response that cause changes in the composition of subgingival plaque with an increase in the number and virulence of pathogenic organisms [4].

Cigarette contains three kinds of hazardous chemicals which are tar, nicotine and carbon monoxide. Besides aesthetic problems, tar build up on teeth may cause tooth surface becomes rough so that easily adhered by plaque [12].

Nicotine in cigarettes damages the immune response and causes constriction of blood vessels, including the blood vessels around the teeth, causing changes in the cells of periodontal tissues [13]. Carbon monoxide in cigarettes can increase blood pressure that affects hemoglobin exchange system [12].

Research conducted by Kumar et al. showed that there were differences in the number of bacterial colonies in smokers and non-smokers which obtained from the margins, subgingival plaque and gingival crevicular fluid [14]. Muller research showed that after six months observation, there was more supragingival plaque found in the group of smokers than non-smokers [15]. Based of a corresponding studies about the difference in the number of bacteria in smokers and non-smokers, researchers are interested in examining differences in the number of bacterial colonies on smokers and non-smokers gingivitis patients.

\section{MATERIALS AND METHODS}

This research was an analytic research with cross sectional design. Population of this research was patients at Periodontics Department, USU Dental Hospital. Sampling was taken with purposive sampling technique. The sample size in this study was 70 subjects consisting of smokers and non-smokers gingivitis patients. This study was approved by ethical commitee from the Faculty of Medicine USU (No. 132/KOMET/FK USU/2016).

The sample criteria included subjects aged 18-60 years, patients with gingivitis and active smokers (at least 1 cigarette per day), patients with gingivitis and non-smokers, general health of subject is good, number of remaining teeth at least 20 teeth and the subjects did not have dental treatment for the past 6 months. Exclusion criteria were patients with periodontitis, systemic diseases, pregnant women, and presence of orthodontic appliances or removable denture.

Retrieval of data begins with provision of informed consent by the subject and interviewed using the questionnaire. The sample was done by application of the disclosing gel (GC Tri Plaque ID Gel) on the entire surface of the tooth. Plaque samples were taken from the lower anterior lingual surfaces of the teeth using a sterile curette, then placed on a paper point number 60 and inserted into the tube-containing $5 \mathrm{~mL}$ phosphate buffer solution. The tube was stored in ice bucket containing ice blue gel to keep the sample at temperature $2-8^{0} \mathrm{C}$. The periodontal clinical subject was examined for gingivitis diagnosis.
Samples were taken to the laboratory in Department of Microbiology, Faculty of Medicine, Universitas Sumatera Utara, to be cultivated in nutrient agar medium at Sapticabinat Class II Biological ESCO (BSC II ESCO) room. Incubation at $37^{\circ} \mathrm{C}$ for 1 times 24 hours. The calculation of the number of bacterial colony is done manually and measured in units of CFU (Colony Forming Unit). Data were analyzed using the Mann-Whitney statistical tests.

\section{RESULTS}

The results showed that the majority subject in this research is male $(65.71 \%)$. According to the age group, the age range 20 until 29 years old is the largest number $(52.85 \%)$. Samples with the profession as a student is the majority among subjects (51.42\%) (Table I).

TABLE I. DEMOGRAPHIC DATA
\begin{tabular}{|l|c|c|c|c|c|c|}
\hline \multicolumn{1}{|c|}{ Variable } & \multicolumn{2}{c|}{ Smokers } & \multicolumn{2}{c|}{$\begin{array}{c}\text { Non- } \\
\text { Smokers }\end{array}$} & \multicolumn{2}{c|}{ Total } \\
\hline & $\begin{array}{c}\text { N } \\
(35)\end{array}$ & $\%$ & $\begin{array}{c}\text { N } \\
(35)\end{array}$ & $\%$ & $\begin{array}{c}\text { N } \\
(70)\end{array}$ & $\%$ \\
\hline Gender & & & & & & \\
\hline Male & 32 & 91.43 & 14 & 40 & 46 & 65.71 \\
\hline Women & 3 & 8.57 & 21 & 60 & 24 & 34.29 \\
\hline Age & & & & & & \\
\hline$<20$ & 4 & 11.42 & 6 & 17.14 & 10 & 14.28 \\
\hline $20-29$ & 15 & 42.85 & 22 & 62.85 & 37 & 52.85 \\
\hline $30-39$ & 9 & 25.73 & 2 & 5.72 & 11 & 15.73 \\
\hline $50-59$ & 5 & 14.28 & 2 & 5.72 & 7 & 10 \\
\hline$>59$ & 2 & 5.72 & 3 & 8.57 & 5 & 7.14 \\
\hline Job & & & & & & \\
\hline Students & 12 & 34.28 & 24 & 68.57 & 36 & 51.42 \\
\hline Self Employed & 13 & 37.15 & 3 & 8.57 & 6 & 22.85 \\
\hline Employees & 8 & 22.85 & 6 & 17.14 & 14 & 20 \\
\hline Housewife & 2 & 5.72 & 2 & 5.72 & 4 & 5.73 \\
\hline
\end{tabular}

Based on the results using the test non-parametric Mann-Whitney, the differences in the number of bacterial colonies in smokers and non-smokers patient gingivitis was significant with $\mathrm{p}=0.001(\mathrm{p}<0.05)$ (Table II).

TABLE II. COMPARISON OF TOTAL COLONY BACTERIA IN GINGIVITIS PATIENTS SMOKERS AND NONSMOKERS

\begin{tabular}{|c|c|c|c|}
\hline $\begin{array}{c}\text { Number of Colonies } \\
\text { of Bacteria }\end{array}$ & N & $\begin{array}{c}\text { Median } \pm \text { Interquartile } \\
\text { (CFU / ml) }\end{array}$ & p \\
\hline Smokers & 35 & $175.00 \pm 136083$ & \multirow{2}{*}{$0.001^{*}$} \\
\hline Non-smokers & 35 & $84.00 \pm 103225$ & \\
\hline \multicolumn{3}{|c|}{${ }^{*}=$ a significant difference ( $\left.<<0.05\right)$} \\
\hline
\end{tabular}

Based on the test results using non-parametric Mann-Whitney, there was a difference in the accumulation of plaque between gingivitis patients smokers and non-smokers with $\mathrm{p}=0.008$ ( $\mathrm{p}<0.005)$ (Table III).

TABLE III. COMPARISON OF PLAQUE ACCUMULATION IN GINGIVITIS PATIENTS SMOKERS AND NON-SMOKERS

\begin{tabular}{|l|c|c|c|}
\hline $\begin{array}{c}\text { Plaque } \\
\text { accumulation }\end{array}$ & $\mathbf{N}$ & $\begin{array}{c}\text { Median } \pm \text { Interquartile } \\
(\mathbf{C F U} / \mathbf{m l})\end{array}$ & $\mathbf{p}$ \\
\hline Smokers & 35 & $19: 20 \pm 64.00$ & $0.008^{*}$ \\
\hline Non-smokers & 35 & $55.80 \pm 12: 20$ & \\
\hline
\end{tabular}




\section{DISCUSSION}

Mostly subject in this study were patients in age group 20-29 years. This corresponds with the Research Health Policy Institute in 2000-2010 in the United States shows that the age group 21-34 years had an increased percentage of visits to the dentist the most compared to other age groups [16]. Samples with the profession as a student become a major priority with the number $36(51.42 \%)$. It shows the level of public awareness towards oral health increases along with the level of education and profession. Increasing public knowledge about oral health makes people seek help from dental health practitioner before the gingival and periodontal tissues infection. RISKESDAS RI 2013 reported that people with higher education seek more dental treatment $(11.1 \%)$ compared to the lower one [17].

In this study, the visible plaque that examined is supragingival plaque. Supragingival plaque affected growth, accumulation and pathogenesis of subgingival plaque, especially at the onset of gingivitis [18].

This study used a nutrient agar as a growth medium of bacterial colonies in petri dish. Nutrient agar, a brown medium, is a medium for growing bacteria. Nutrient agar, in the form of a solid, is a blend of natural ingredients and chemical compounds. Medium contains a nitrogen source in sufficient amount to be used in the cultivation of bacteria for the calculation of microorganisms in water, sewage, dirt and other materials $[19,20]$. This is in contrast with the blood agar, which is a medium used to differentiate organisms or groups of organisms to be studied. The presence of certain dyes or chemicals that produce characteristic changes in the media or growth patterns was used for identification or differentiation $[19,21]$.

In this study, a significant difference $(p=0.001)$ between the number of colonies of bacteria in the patient group of smokers (175.00 CFU / ml) and nonsmokers (84.00 CFU / ml). Kumar et al. showed that there were differences in the number of bacterial colonies in smokers and non-smokers were taken from the margin, subgingival plaque and gingival sulcus fluids [14]. Differences in the number of bacterial colonies in smokers due to exposure to tobacco affect the bacterial composition of the plaque. Diversity colonies were found more in smokers than nonsmokers. Thus, microbial communities showed lower stability after 7 days in smokers than non-smokers [14].

In this study, there are differences in plaque accumulation between groups of smokers and nonsmokers patients. The accumulation of plaque was found higher in smokers than non-smokers. Torkzaban et al. stated that there were significant differences between smokers and non-smokers, as the smokers have higher accumulation of plaque than non-smokers [22]. Smoking can affect the mechanism of the host and the changes of oral microorganisms associated with periodontal disease. In addition, the risk of smokers having periodontitis is two to eight times higher than non-smokers [23].
As a conclusion, there are significant differences between the number of bacterial colonies on smokers and non-smokers gingivitis patients, and there are differences in the accumulation of plaque in smokers and non-smokers.

\section{ACKNOWLEDGMENT}

Acknowledgments are addressed to the Minister of Research, Technology and Higher Education of Indonesia, at the expense of this study was derived from DRPM Directorate General of Strengthening Risbang in 2017.

\section{REFERENCES}

[1] S.A. Widodo, K. Banun, W.A.F. Dwi, "Identifikasi bentuk sel bakteri anaerob berdasarkan warna koloni pada gingival crevicular fluid pasien gingivitis kronis dan periodontitis kronis," Artikel Ilmiah. Jember, pp. 1-5, 2014.

[2] D.R. Tuhuteri, B.S. Lampus, N.S.W. Vonny. (2015, October 5) Status kebersihan gigi dan mulut pasien poliklinik gigi Puskesmas Paniki Bawah Manado. Available: www.download.portal-garuda.org.

[3] J. Tanjaya, E.L. Auerki, "IL-1ß genetic polymorphism in menopause women as periodontal disease risk factor," $\mathrm{J}$. Dentistry Indonesia, vol. 18(1), pp. 1-2, 2011.

[4] B.M. Eley, M. Soory, J.D. Manson, Periodontics, $6^{\text {th }}$ ed., Toronto: Elsevier, 2010, pp. 1, 19-25.

[5] S. Pintauli, Penyakit periodontal: Pengukuran resiko dan evaluasi. In: Menuju gigi dan mulut sehat pencegahan dan pemeliharaan, Edisi Revisi. Medan: USU Press, 2015, pp. 2930 .

[6] A.D.F.V. Pereira, C.S.V. Ana, D.L.R. Quezia, M.C.A. Claudia, L.A.P. Antonio, "Effect of cigarette smoking on oral hygiene status,” J. Dent. Science, vol. 28(1), pp. 4-7, 2013.

[7] M. Sreedevi, R. Alampalli, D. Chini, "Periodontal status in smoker and nonsmoker: A clinical, microbiology, and histopathological study," International Journal of Dentistry, vol. 1-10, 2011.

[8] I.T. Notoharjo, L. Andayasari, "Nilai kebersihan gigi dan mulut pada karyawan industri Pulo Gadung di Jakarta," Buletin Penelitian Sistem Kesehatan, vol. 16(2), pp. 168-170, 2013.

[9] R. Alamsyah, L. Natamiharja, H. Rika, "Hubungan kebiasaan merokok dengan status periodontal tukang becak di sekitar Kampus USU Medan,” Dentika, vol. 17(2), Abstract, 2012.

[10] Departemen Kesehatan Republik Indonesia, Riset kesehatan dasar, Jakarta, 2013, pp. 132-137, 146-154.

[11] A. Pejcic, R. Obradovic, L. Kesic, D. Kojovic, "Smoking and periodontal disease: A review," Medicine and Biology, vol. 14(2), pp. 53-59, 2007.

[12] A.D.R.P. Kusuma. (2015, August 27) Pengaruh merokok terhadap kesehatan gigi dan rongga mulut. Available: www.unissula.ac.id.

[13] K. Eddy, "Merokok sebagai faktor risiko terjadinya penyakit periodontal,” J. Kedokteran Trisakti, vol. 20(1), pp. 9-15, 2001.

[14] P.S. Kumar, R.M. Chad, J. Vinayak, J. Marko, Marclo, “A tobacco smoking affects bacterial acquisition and colonization in oral biofilms," J. Am. Soc. Microbiology, vol. 79, pp. 11, 2011.

[15] H.P. Muller, S. Stadermann, Hetnecke, "Longitudinal association between plaque and gingival bleeding in smoker and non-smokers," J. Clin. Periodontal, vol. 29, pp. 287-294, 2002.

[16] I.T. Notoharjo, X.S.H. Frans, "Gambaran kebersihan mulut dan gingivitis pada murid sekolah dasar di Puskesmas Sepatan Kabupaten Tangerang," J. Media Litbang. Kesehatan, vol. 20(4), pp. 1-9, 2010.

[17] S. Notoatmodjo, Metodologi penelitian kesehatan. Jakarta: Rineka Cipta, 2010, pp. 25-26.

[18] T. Wall, K. Nasseh, "Dental-related emergency department visits on the increase in the united states," Health Policy Institute ADA, pp. 3, 2013. 
[19] G.J. Arthur, R.J. Ziegler, L. Hawley, Essential mikrobiologi dan imunologi, Alih Bahasa: J.E. Surjawidjaja, Tangerang Selatan: Binarupa Aksara, 2011, pp. 33-3.

[20] N.N. Jalayer, H. Semyari, Z. Elahinia, "The impact of smoking on gingiva: A histopathological study," Iranian Journal of Pathology, vol. 10(3), pp. 214-220, 2015.
[21] A. Sagar. (2016, April 12) Nutrient agar: Composition, preparation and uses. Available: http://www.microbiologyinfo. com/nutrient-agar-composition-preparation-and-uses.

[22] T. Parviz, Z. Khalili, N. Ziaei, "Smoking and periodontal diseases," Avicenna J. Dent. Res., vol. 5(2), pp. 1-7, June 2013.

[23] M. Ta'a Abu, "The effects of smoking on periodontal diseases: An evidence-based comprehensive literature review," Open Journal of Stomatology, vol. 4, pp. 33-41, January 2014. 